\title{
PROBLEMY Z PRÓBAMI, DYSKRYMINACJĄ RASOWĄ I EDUKACJĄ: EKONOMETRIA I ZAGADNIENIA SPOŁECZNE W PRACY JAMESA J. HECKMANA (Nagroda imienia Nobla, 2000)
}

ŚLĄSKI

PRZEGLĄD

STATYSTYCZNY

Nr 13(19)

\section{Katarzyna Ostasiewicz \\ Uniwersytet Ekonomiczny we Wrocławiu}

DOI: $10.15611 / \mathrm{sps} .2015 .13 .15$

\begin{abstract}
Streszczenie: James J. Heckman, ekonomista zaliczany do tzw. szkoły chicagowskiej, został uhonorowany Nagrodą imienia Nobla w roku 2000. Jego głównym wkładem w dziedzinę mikroekonomii były statystyczne metody wyciągania wniosków z danych pochodzących z wyselekcjonowanych prób. Na polu nauk społecznych Heckman stał się jednym z czołowych badaczy interesujących się zagadnieniami dyskryminacji rasowej oraz edukacji, ze szczególnym naciskiem na pozapoznawcze aspekty wczesnego nauczania.
\end{abstract}

Słowa kluczowe: model ekonometryczny; wyselekcjonowana próba; pozapoznawcze aspekty nauczania; J.J. Heckman.

\section{Wstęp}

W 1944 r., w Chicago, w pobliżu słynącego z wolnorynkowych ekonomistów Uniwersytetu Chicagowskiego, przyszedł na świat pewien chłopiec.

Istnieją niezmiernie interesujące badania wskazujące na pozornie absurdalne w swej prostocie zależności: że osoby o imieniu zaczynającym się na głoskę „,den” (Dennis, Denice,...) częściej, niżby to wynikało z reprezentacji w ogóle populacji, zostają dentystami; natomiast Lawrence czy Laura $\mathrm{z}$ większym prawdopodobieństwem wybiorą zawód prawnika (ang. lawyer) [Pelham i in. 2002].

W tym kontekście można się zastanowić: czy zupełnym przypadkiem stało się tak, że ów chłopiec z pobliża Uniwersytetu Chicagowskiego, po różnych peregrynacjach, zarówno geograficznych, jak i intelektualnych, powrócił w obydwu znaczeniach do miejsca swoich narodzin? Mowa bowiem o Jamesie Josephie Heckmanie, profesorze Uniwersytetu Chicagowskiego, wielbicielu Miltona Friedmana, koledze Gary'ego Beckera, laureacie Nagrody Banku Szwecji imienia Alfreda Nobla za rok 2000. 


\section{Peregrynacje}

Nr 13(19)

We wczesnym dzieciństwie małego Jamesa rodzina przeprowadziła się na południe Stanów Zjednoczonych. Tam przyszły uczony doświadczył istnienia segregacji rasowej $\mathrm{i}$ - jak sam pisał w swojej nocie autobiograficznej - uwrażliwił się na losy mniejszości, który to wątek przewijać się będzie w jego późniejszej pracy naukowej. Rys osobisty tej wrażliwości nadała przyjaźń ze studentem nigeryjskiego pochodzenia.

Jak w przypadku wielu innych ekonomistów, ekonomia nie była pierwszym naukowym wyborem Heckmana. W latach edukacji na poziomie odpowiadającym polskiemu liceum, w Lakewood, Heckman zafascynowany był fizyką, pozostając pod silnym wpływem Franka Oppenheimera. Interesującym faktem jest to, iż Frank Oppenheimer brat sławniejszego niż on sam „ojca bomby atomowej” - był członkiem Partii Komunistycznej. Jakże dalekie są idee komunistyczne od gloryfikacji wolnego rynku przez późniejszych mentorów Heckmana. Jednakże, jeśli nie wizja społeczeństwa, to przynajmniej metodyka badań zaszczepiona została przez Oppenheimera młodszemu podopiecznemu: w dalszym ciągu pracy naukowej, nawet po zmianie dziedziny na ekonomię, Heckman przykładał największą wagę do konfrontowania teorii z danymi empirycznymi.

Porzuciwszy fizykę, Heckman kontynuował naukę w Kolorado Springs, jako specjalność wybierając z kolei matematykę. Uzyskany w ten sposób bogaty zestaw matematycznych narzędzi stanowił drugi filar - po solidnym wprowadzeniu w metodologię nauk empirycznych - umożliwiający podjęcie badań w dziedzinie, która miała okazać się jego docelowym portem: mikroekonomii.

Pierwsze głębsze spotkanie z ekonomią i w szczególności Chicagowską jej szkołą miało miejsce tuż po ukończeniu koledżu. Krótki okres nauki na Uniwersytecie w Chicago zrodził fascynację ideami Miltona Friedmana. Nim koniec końców osiadł na stałe na tej uczelni, już jako badacz a nie student, Heckman zaliczył w międzyczasie Princeton i Uniwersytet Columbia. Jednakże, przemieszczając się w sensie geograficznym, pozostawał już stałym w swoich naukowych wyborach, pogłębiając je tylko i poszerzając. Stopniowo klarowało się zainteresowanie Heckmana rozwijaniem i wykorzystywaniem metod ekonometrycznych w zastosowaniu do badania rynku pracy i możliwości wpływu na niego za pomocą różnych interwencji i programów. Tym samym, zostając w 1974 r. profesorem Uniwersytetu w Chicago, Heckman wpisywał się już zdecydowanie w dziedzinę mikroekonomii, w odróżnieniu od siostrzanej dziedziny - ekonomii w skali makro. 
Jeśli spojrzeć na werdykty Królewskiej Szwedzkiej Akademii Nauk, przyznającej od 1969 r. Nagrody imienia Nobla w dziedzinie ekonomii, mikro- i makroekonomia pojawiają się w równych proporcjach. Niektórzy ekonomiści, jak John Kenneth Galbraith, w ogóle uważają takie rozróżnienie za sztuczne. Co prawda te subdziedziny różnią się obiektem swoich badań: wybranych sektorów gospodarki bądź gospodarką jako całością, jednakże obie one opierają się na analizie działań jednostek, ich reakcji na bodźce płynące $\mathrm{z}$ rynku i od innych konsumentów. Etymologicznie, samo określenie „ekonomia” z języka greckiego oznacza zasady prowadzenia gospodarstwa domowego, co sugeruje raczej operowanie w skali „mikro”. „Poza opłotki gospodarstwa domowego" [Klimczak 2015] myśl ekonomiczna wyszła na początku wieku XVII, za sprawą merkantylistów, którzy po raz pierwszy użyli określenia „ekonomia polityczna”.

Idee późniejszych teoretyków ekonomii mieszały ze sobą motywacje poszczególnych jednostek i działanie rynku jako całości. Wyznacznikiem myśli makroekonomicznej mogłoby być może postulowanie emergentnych własności globalnej gospodarki. Po raz pierwszy wątek ten pojawił się u fizjokratów, zakładających, iż gospodarka rządzi się autonomicznymi prawami, niezależnymi od działań poszczególnych jednostek. Abstrahując od ontologicznego statusu tych domniemanych praw, również współcześnie makroekonomia posługuje się bardziej ,zagregowanymi” równaniami na podobieństwo termodynamiki fenomenologicznej, uśredniając poniekąd po licznych indywiduach. Mikroekonomia tymczasem skupia się raczej na budowaniu modeli, opisujących (i przewidujących) decyzje pojedynczych uczestników rynku, wchodząc $w$ nierozerwalny związek $\mathrm{z}$ ekonometrią. $\mathrm{Z}$ matematycznego punktu widzenia tworzenie - a raczej rozwiązywanie - takich modeli wymaga albo wyrafinowanych narzędzi matematycznych, albo niesamowitych mocy obliczeniowych. Ku niekłamanemu żalowi wielu naukowców o staroświeckim zamiłowaniu do obliczeń analitycznych, rozwój technologii komputerowych powoduje, że sprytne przybliżenia coraz bardziej tracą na wartości, stając się estetycznymi ciekawostkami. Studenci wciąż uczeni są eleganckiego twierdzenia de Moivre'a-Laplace'a, choć większość programów komputerowych potrafi poradzić sobie ze ścisłymi obliczeniami numerycznymi nawet dla dużych prób. Być może nieodległy jest już moment, gdy ktoś zdecyduje, że to przybliżenie nie jest obecnie do niczego potrzebne. Być może również, gdyby Heckman opracował poprawkę nazwaną jego nazwiskiem na początku XXI w., zamiast 
w latach 70. XX w., nie zostałby wyróżniony Nagrodą imienia Nobla za swój wkład w dziedzinę analizy ekonomicznej - a przynajmniej, nie za ten element swojego wkładu. Nim jednak przyjrzymy się dokładniej dość technicznemu osiągnięciu Heckmana, spójrzmy bliżej na to, co leży u podstaw formułowania modeli mikroekonomicznych. Podstaw, podkreślmy, obecnie dość kontrowersyjnych, a będących jednym z przedmiotów, w których nasz bohater również zabierał głos na forum naukowym i publicznym.

\section{Szkoła chicagowska i racjonalność}

Pierwszą znaczącą próbą opisania indywidualnych wyborów konsumenckich były zasady zapostulowane przez szwajcarskiego matematyka, Mikołaja Bernoulliego (1695-1726). Wedle nich, jednostki dokonywały racjonalnych wyborów dzięki przewidywaniu stopnia satysfakcji z dokonania takiego czy innego zakupu. Interesujące, że pomimo upływu trzech wieków i wysiłków niezliczonych następców, wyposażonych w o wiele lepsze narzędzia, zarówno eksperymentalne, jak i obliczeniowe, wśród naukowców działających na polu ekonomii wciąż toczy się spór o zasadność tego modelu: stopień racjonalności oraz przewidywalność ludzkich wyborów.

W obronie naszego rozsądku powstawały kolejno różne teorie: hipoteza oczekiwań adaptacyjnych, teoria racjonalnych oczekiwań, teoria oczekiwanej użyteczności... Tymczasem ludzie uparcie bronią się przed wpasowaniem w schematy jakichkolwiek matematycznych aksjomatów, zadziwiając i irytując badaczy swoimi niekonsekwentnymi i nieprzewidywalnymi zachowaniami.

Stosunkowo nowoczesnym trendem w nauce jest podkreślanie tego żywotnego anarchizmu ludzkich decyzji. Jednakże od chwili swoich narodzin nurt ten przebojem niemalże zdobywa kolejnych zwolenników, również wśród oczytanych laików. Na gruncie psychologii i ekonomii behawioralnej wielokrotnie udowadniano, iż decyzje jednostek ludzkich nie spełniają zakładanych w neoklasycznej teorii ekonomii aksjomatów. Można by pokusić się o złośliwość i stwierdzić, że sama Królewska Szwedzka Akademia Nauk jest ucieleśnieniem niekonsekwencji wyborów, przyznając najważniejszą ekonomiczną nagrodę na przemian: zwolennikom poglądu o racjonalności oraz piewcom irracjonalności uczestników rynku.

Jako pierwszy, z ideami ograniczonej racjonalności, przebił się do głównego nurtu nauki Herbert Simon [1957]. Za swoje prace, ukazujące, iż ludzie zazwyczaj nie poszukują rozwiązań najlepszych, a je- 
dynie dostatecznie dobrych, uhonorowany został Nagrodą imienia

Nobla w 1978 r. Dziś, gdy na półkach w księgarniach zalegają stosy książek o tytułach typu Żyj wystarczajaco dobrze [Jucewicz i SroSTATYSTYCZNY czyński 2013] czy A Good Enough Parent [Bettelheim 1987] wydawać się to może niemalże truizmem. Dodatkowo, tacy badacze jak Barry Schwarz podnoszą, iż dążenie do optymalizacji decyzji jest najprostszą drogą do unieszczęśliwienia się [Schwarz 2013]. Co jeszcze ciekawsze, badania zupełnie odległe od ekonomicznych teorii zachowań konsumenckich pokazują, iż stuprocentowa racjonalność jest w istocie irracjonalna i uniemożliwia życie. Neuronaukowiec Antonio Damasio opisuje przypadek pacjenta, któremu specyficzne uszkodzenie mózgu „wyłączyło" emocjonalny komponent podejmowania decyzji [Damasio 2000]. Okazało się, że najprostsze czynności - typu ubieranie butów - wymagają, jeśli podchodzić do nich ściśle racjonalnie, zbyt wielkich mocy obliczeniowych i powodują zawieszenie systemu. Bo istotnie: jak rozważyć wszystkie za i przeciw nałożeniu buta prawego przed lewym? Przypomina to sytuację osiołka Buridana, któremu absolutnie symetryczna sytuacja dwóch źródeł pożywienia uniemożliwia podjęcie decyzji (doskonała symetria!) i powoduje śmierć głodową. Pewna doza bezmyślności, losowości, czy nawet lekka nerwica natręctw (,za nic w świecie nie rozpoczynać od lewego buta!') mają w podobnych sytuacjach niekwestionowane zalety.

Po raz kolejny Nagroda imienia Nobla trafiła w ręce osoby kwestionującej ludzką racjonalność $\mathrm{w}$ roku 2002. Otrzymał ją psycholog, Daniel Kahneman, który poszedł krok dalej niż Simon. Wskazywał on bowiem nie tylko na ograniczenia racjonalności. To było jeszcze może do przełknięcia: nawet programy komputerowe znajdują często tylko „lokalne” ekstremum, nie będąc w stanie przeszukać całego pejzażu możliwości w celu zidentyfikowania ekstremum „globalnego”. Nie poprzestając na tym, Kahneman - wespół z Amosem Tverskim - podkreślał jawną irracjonalność zachowań. To było jak policzek wymierzony naszemu intelektowi. Bo jak inaczej odebrać rewelacje, iż nasze decyzje są inne w zależności od tego, czy rezultat przedstawiony nam zostanie jako czterdziestoprocentowe prawdopodobieństwo wygranej czy też sześćdziesięcioprocentowe prawdopodobieństwo przegranej? Wszak wiadomo, że jedno i drugie sformułowanie oznacza to samo. Oznacza to samo, ale stanowi inną perspektywę, wskazywali naukowcy badający tę sytuację i wiele podobnych [Kahneman 2012].

Wielu badaczy zaczęło wskazywać, iż zamiast załamywać ręce nad tym godnym ubolewania stanem rzeczy, należałoby lepiej rozpoznać skróty - czyli heurystyki - jakimi posługuje się przeciętny ludzki 
umysł. Częściowo po to, aby uniknąć ich negatywnych skutków. Robert J. Schiller, laureat Nagrody imienia Nobla z 2013 r. i autor książki Zwierzęce instynkty [Akerlof i Schiller 2011] - nie mając złudzeń odnośnie racjonalności i efektywności ludzkich poczynań, co najmniej na rok przed wielkim krachem przestrzegał przed pęknięciem bańki nieruchomościowej. Inni autorzy, jak Richard H. Thaler, współautor książki Impuls [Thaler i Sunstein 2008], idą jeszcze dalej, proponując zaprząc nasze bezrozumne inklinacje w służbę budowania lepszego życia dla wszystkich. Wskazują, że właściwe rządowe interwencje jak na przykład tworzenie odpowiednich „opcji domyślnych” - skutkować może znacznie korzystniejszym społecznie wynikiem. Najbardziej znanym przykładem jest różnica w procencie dawców organów w, przykładowo, Niemczech (12\%) i Austrii (niemal 100\%). Kraje te, bardzo zbliżone kulturowo, różnią się jeśli chodzi o dawstwo organów tym, iż w Niemczech należy wyrazić świadomą zgodę na bycie dawcą, natomiast w Austrii zgoda jest opcją domyślną - choć każdy obywatel ma prawo złożyć deklarację odmowy.

Sądząc po ilości publikacji na temat irracjonalności - zarówno naukowych, jak i przeznaczonych dla szerokiego odbiorcy - wydawać by się mogło, iż jej istnienie w ludzkim myśleniu zostało już powszechnie zaakceptowane. Kwestią, o którą toczyć się może spór jest to, czy irracjonalność ta jest błogosławieństwem (zalety intuicji i szybkiego przetwarzania informacji) - jak przekonuje na przykład Dan Ariely w Zaletach irracjonalności [Ariely 2010] - czy też przekleństwem (wszystkie manowce, na jakie nas wiedzie). A jednak o dziwo! - teoria racjonalnego wyboru miewa się całkiem dobrze. Broniona jest na różnorakie sposoby. Niektórzy postulują quasi-racjonalność ekonomiczną, widoczną $\mathrm{w}$ większej skali, jeśli nie $\mathrm{w}$ działaniach jednostek. Przypomina to dyskusje z początków formowania się statystyki jako dziedziny naukowej: jak pogodzić wolną wolę ludzi z obserwowanymi wzorcami wyłaniającymi się na poziomie całych społeczeństw? W podobny sposób irracjonalne bądź nawet chaotyczne działania poszczególnych osób mogą komponować się $\mathrm{w}$ większy wzór mający znamiona racjonalności. Wszak, jak zauważa Gary Becker [1962], każda decyzja ekonomiczna ograniczona jest dostępnymi środkami, a nawet najbardziej irracjonalna firma nie może na dłuższą metę podejmować deficytowych działań. W opinii oponentów, takie próby utrzymania postulatu racjonalności są jednakże niemal desperackim już dążeniem za wszelką cenę do zachowania zgrabnego aparatu teoretycznego, wypracowywanego przez pokolenia ekonomistów. Warto zwrócić uwagę na jeszcze jeden - dla niektórych 
najważniejszy, bo ideologiczny - aspekt sporu o racjonalność. Otóż dla wielu wyznawców poglądu o racjonalności działań podmiotów gospodarczych jest on dostatecznym argumentem przeciwko większoSTATYSTYCZNY ści możliwych regulacji wolnego rynku.

James Heckman zasadniczo utożsamia się z chicagowską szkołą ekonomii. Niemniej, pod niektórymi względami pozwala sobie na jak sam to określa - „herezje” [Heckman 2010b]. Choć przyznać trzeba, że w kwestii racjonalności nawet najbardziej ikoniczni przedstawiciele szkoły chicagowskiej nie zawsze są tak skrajni, jak się powszechnie przyjmuje. W jednym z wywiadów Heckman [2010b] przytacza wypowiedź samego Miltona Friedmana. Po wysłuchaniu obrony doktoratu zagorzałego wyznawcy szkoły chicagowskiej - przy czym praca doktorska dotyczyła właśnie teorii racjonalnych oczekiwań - Friedman miał wygłosić następujący komentarz: „Myślę, że to dobry pomysł, ale ci faceci poszli z nim o wiele za daleko".

Najdalej poszedł prawdopodobnie Robert Lucas, z którego nazwiskiem teoria racjonalnych oczekiwań jest powszechnie kojarzona. Twierdził on, iż podejmowanie decyzji na podstawie modeli ekonometrycznych opartych na historycznych danych jest z gruntu wiodące na manowce, gdyż każdy (racjonalny) gracz rynkowy ma dostęp do tych samych informacji i wyciąga te same (racjonalne) wnioski. Sama prognoza staje się zatem niejako elementem układanki, który należałoby uwzględnić. W szczególności Lucas twierdził, iż polityka rządu sterującego inflacją $\mathrm{w}$ celu zmniejszenia stopy bezrobocia będzie wpływała na oczekiwania przedsiębiorców odnośnie stopy inflacji a co za tym idzie - na ich decyzje o zatrudnianiu. Wywody te znane są pod nazwą „krytyki Lucasa”. Określenie „krytyka Lucasa” może być jednak rozumiane dwojako. W konwencjonalnych sensie, znanym z podręczników ekonomii, jest to krytyka autorstwa Lucasa. Można pokusić się jednakże również o inne rozumienie i skrytykować Lucasa. Tego właśnie dokonuje Heckman, twierdząc w wywiadzie: „,...] Dane odrzucają teorię [racjonalnych oczekiwań]. Lucas [...] zajmuje się głównie teorią. Nie stawia zbyt wielu stwierdzeń empirycznych" [Heckman 2010b, s. 4] - które, zaznaczmy, mogłyby zostać poddane falsyfikacji. Heckman, jako adept fizyki w młodych latach, doskonale zdaje sobie sprawę z metodologii nauk empirycznych. „Nie sadzę”, dodał lojalnie, „by Bob dał się ponieść. Ale niektórzy z jego uczniów tak. To się często zdarza. Im niżej się przesuwamy w łańcuchu pokarmowym, tym więcej zaciekłych i fanatycznych wyznawców" [Heckman 2010b, s. 4]. 
Pomimo tego - zdawałoby się - wyważonego podejścia, Heckman nie zgadza się z Schillerem, iż za kryzys w branży nieruchomości odpowiedzialne były „zwierzęce instynkty”. Przeciwnie, twierdzi. Ludzie zachowywali się adekwatnie do sygnałów płynących z rynku. Kwestią zasadniczą jest to, iż to rynek reagował zbyt wolno na zmieniającą się sytuację. Żadne dane empiryczne, upiera się Heckman, nigdy nie podważyły stwierdzenia, iż ludzie i podmioty gospodarcze w racjonalny sposób reagują na rynkowe bodźce [Heckman 2010b] (Zauważmy, iż nie jest to tożsame $\mathrm{z}$ hipotezą racjonalnych oczekiwań, zakładającą dużo większe możliwości intelektualne i perspektywiczne uczestników rynku). Heckman nie komentuje przy tym w żaden sposób choćby rezultatów eksperymentów typu ,ultimatum”, w których uczestnicy odrzucają ewidentnie korzystne propozycje, gdy zostają one uznane za „niesprawiedliwe”. Cieszący się sporą popularnością w Internecie filmik, pokazujący identyczne oburzenie moralne małpek kapucynek, postawionych w obliczu „nieuczciwej” - acz korzystnej - oferty (prezentacja oparta na eksperymentach Fransa de Waala [de Waal 2013]), zdaje się uzasadniać użycie przez Akerlofa i Schillera określenia „,zwierzęce instynkty" w tytule książki opozycyjnej do Heckmana.

Tak czy siak, zauważmy, że aby bronić jednego z filarów chicagowskiej szkoły ekonomicznej, Heckman zmuszony jest podważać inny: hipotezę o efektywności rynku. Najwyraźniej nie jest, wbrew stereotypowi, aż tak entuzjastycznym zwolennikiem deregulacji, gdyż w wywiadzie wręcz zarzuca zbyt małe regulacje sektora finansowego, prowadzące do kryzysów, w szczególności ostatniego wielkiego kryzysu światowej gospodarki.

Jak widać, chicagowska szkoła - wbrew pozorom - nie jest monolitem, jeśli chodzi o poglądy. Sam Heckman zauważa w wywiadzie: „Mamy tu wielką różnorodność. Możesz przejść się od gabinetu do gabinetu i poznać zupełnie odmienne punkty widzenia" [Heckman 2013]. Wydaje się, że w jego przypadku kluczową rolę odgrywa zakorzenienie w twardych danych. Jak zobaczymy później, Heckman jest bardziej Heckmanem, niż ekonomistą szkoły chicagowskiej.

Dane społeczne i ekonomiczne mają przeważnie zupełnie odmienny charakter niż dane uzyskiwane w eksperymentach fizycznych czy innych dziedzinach nauk przyrodniczych. Przede wszystkim, zazwyczaj są one rezultatem pewnych „eksperymentów naturalnych”, nad którymi badacz nie ma żadnej kontroli. Jego rolą jest natomiast zrobienie jak najlepszego użytku z niepełnych wyników. Jest jak detektyw, którego zadaniem jest połączenie dostępnych kropek w całościowy kształt. Rzecz jasna, możliwości tych połączeń jest przeważnie 
bardzo wiele. Należy to zatem zrobić w sposób najbardziej wiarygodny, i tu na scenę wkraczają statystyczne metody opracowywania danych - czyli działka, za którą Heckman uhonorowany został Nagrodą imienia Nobla.

\section{Dane, modele i przyczynowość}

Mikroekonomia rozwinęła skrzydła dopiero jakoś koło połowy ubiegłego wieku. Przyczyny jakościowego niemal skoku były z grubsza rzecz ujmując trzy [Donohue 2001]. Po pierwsze, dzięki decyzjom politycznym dostępne stały się całe zbiory danych dotyczących pojedynczych uczestników rynku. Po drugie, moce obliczeniowe komputerów wzrosły na tyle, że realistycznym stało się ogarnięcie tych milionów liczb. Po trzecie w końcu, katalizowany prawdopodobnie przez dwa pierwsze, intelektualny wysiłek wielu zdolnych uczonych uzbroił badaczy w konceptualne narzędzia i idee, leżące u podstaw pracy $\mathrm{z}$ danymi.

Choć w mediach co i raz pojawiają się doniesienia polegające na wyciąganiu wniosków z dostępnych danych, w znacznej mierze są one niewiarygodne $\mathrm{z}$ naukowego punktu widzenia. Jeśli na opakowaniu kremu do twarzy przeczytamy, iż niemal 86\% użytkowników raportuje poprawę stanu skóry po jego użyciu, a następnie doczytamy napisane drobnym drukiem wyjaśnienie, że badanych było 7 osób, budzić to może tylko pobłażliwy uśmiech. Wiele innych jednakże badań, publikowanych nawet $\mathrm{w}$ poważnych opracowaniach czy publikacjach naukowych i mających pretensje do ścisłości, cechuje się wieloma niedociągnięciami metodycznymi. Częstokroć są one nawet zamierzone, jak to nieraz ujawniano $\mathrm{w}$ przypadku badań sponsorowanych przez firmy farmaceutyczne [Goldacre 2013]. Często jednakże szczere chęci i uczciwość badawcza padają ofiarą pewnej naiwności w pojmowaniu przyczynowości i prób identyfikowania czynników sprawczych.

Choć tak zdroworozsądkowa, przyczynowość - oraz jej poznawalność - bywała kwestionowana od dawna. Najsłynniejszej być może krytyce poddał ją osiemnastowieczny historyk i filozof, David Hume. Skąd wiedzieć możemy, stawiał pytanie, że naciśnięcie spustu strzelby i następujący po nim huk są powiązane przyczynowo? Być może, złośliwy służący wyjął ze strzelby naboje, a stojąc za naszymi plecami wytwarza huk za każdym razem, gdy naciskamy spust [Hume 1777].

Pomni na możliwość rozmaitych sztuczek świata przyrody i świata społecznego, nie ograniczających się do celowych złośliwości służących, naukowcy od dziesięcioleci starają się wypracować metodologię 
identyfikowania przyczyn sprawczych. Bo tak naprawdę tym, co jest istotne w nauce stosowanej, jest możliwość zaprzęgnięcia jej do zmieniania świata - a co za tym idzie, przewidywania skutków rozmaitych działań. Jednym ze słynnych pionierów praktycznego wykorzystania statystyki był XIX-wieczny lekarz John Snow. Gdy w trakcie szalejącej w Londynie epidemii cholery zauważył on, iż przypadki zachorowań współwystępowały z korzystaniem z pewnej konkretnej pompy przy Broad Street, zdemontował jej uchwyt, zmuszając ludzi do czerpania wody z mniej zanieczyszczonych ujęć, dzięki czemu zahamował rozwój choroby. Oczywiście, cokolwiek by twierdzili purystyczni teoretycy statystyki, „współwystępowanie” zostało przez Snowa zinterpretowane jako zależność przyczynowo-skutkowa. Gdyby było po prostu tak, że w okolicy obsługiwanej przez pompę zamieszkują ludzie podatni z przyczyn genetycznych na tę konkretną chorobę, zablokowanie ujęcia nie dałoby żadnego rezultatu. Była i taka możliwość, jednakże Snow nie ryzykował zbyt wiele, gdyby jego analiza była błędna. Zdemontowanie czy ponowne zamontowanie uchwytu do pompy nie były ani specjalnie kosztownymi działaniami, ani nie niosły ze sobą potencjalnie groźnych reperkusji. Jednakże w wielu innych przypadkach, zwłaszcza we współczesnym świecie, w którym każde działanie odbywa się na większą skalę, częstokroć krytyczne jest prawidłowe rozpoznanie zależności przyczynowo-skutkowych i uprzednie rozpoznawanie potencjalnych skutków.

Statystyka i ekonometria wypracowały dwa odmienne paradygmaty identyfikowania takich zależności. Żaden z nich nie jest odporny na krytykę, a skuteczność ich działania można by określić jako „asymptotyczną". Im więcej bowiem stopni komplikacji i potencjalnych czynników włączymy do analizy, tym bardziej pewni możemy być jej rezultatów. Niestety, ta ,asymptotyczność” nie jest dosłowna w sensie naukowym: nikt nigdy nie wykazał, w jaki sposób mamy włączać kolejne stopnie złożoności, by w satysfakcjonującym stopniu zbliżać się do prawdy (jakkolwiek byśmy ją rozumieli).

Oba paradygmaty opierają się na intuicyjnym rozumieniu przyczynowości, którego adwokatem był John Stuart Mill [1848]. Jeśli powtórzymy dwukrotnie doświadczenie identyczne pod każdym względem prócz jednego czynnika, to różnica rezultatów jest spowodowana tym czynnikiem [Heckman 2005]. Definicja całkiem sensowna; gorzej, że w praktyce nie da jej się wykorzystać bez obudowania jej pokaźnym rusztowaniem zaawansowanych metod analizy danych. 
Podejście statystyczne zasadza się na eksperymencie. Najchętniej potraktowalibyśmy badany obiekt w sposób X, następnie cofnęli czas do punktu wyjścia i zastosowali odmienne podejście,Y, ściśle według definicji. Wydaje się to całkiem zdroworozsądkowe. Mniej zdroworozsądkowym jest oczekiwanie, że uda nam się cofnąć czas. Ponadto, zidentyfikowalibyśmy zależność przyczynowo-skutkową dla konkretnego obiektu, i nie mielibyśmy gwarancji, że dla innego różnica efektów zostanie powtórzona. $Z$ rozpoznania tych trudności i w próbie jak najlepszego ich obejścia wyłoniła się współczesna metodyka testowania leków. Opiera się ona na dwóch głównych elementach. Pierwszy to uśrednianie. Liczymy na to, że jeśli (dostatecznie duża) próba zawiera elementy (osoby) dobrane losowo, to na każdy element z odchylenia na plus - względem jakiejkolwiek cechy - przypadnie inna, z odchyleniem na minus, i w ten sposób uśrednione wyniki ukażą nam rezultat reprezentatywny dla całej interesującej nas populacji. Drugi element to eliminowanie współzależności. Ostatnie wypadki w sposób tragiczny uświadomiły społeczeństwu, że rezultaty działań podjętych wobec jednostki zależą od działań wobec innych. Śmierć półtorarocznego chłopca na odrę spowodowana była nie tylko tym, iż nie był on odporny wobec wirusa. Wirus najprawdopodobniej nie zaatakowałby go, gdyby ograniczenie wskaźnika szczepień w Niemczech nie doprowadziło do jego rozprzestrzenienia. Z obydwoma tymi zniekształcającymi rezultaty efektami badacze walczą za pomocą wyrafinowanych metod statystycznych, których stosowaniu sprzyjają jak największe próby z jak najlepiej określonymi wszystkimi cechami. Cały ten paradygmat nazywany jest przyczynowym modelem Neymana-Rubina. Warto podkreślić, iż Jerzy Spława-Neyman był wybitnym polskim naukowcem, pionierem wielu działów statystyki, w tym testowania hipotez.

Podejście ekonometryczne, którego pionierami byli Alfred Marshall [1890] i Trygve Haavelmo [1943] opiera się na z góry przyjętym modelu teoretycznym. Podobnie jak w podejściu statystycznym, nie musimy znać wszystkich czynników wpływających na dane zjawisko. W modelu jest miejsce na „człon losowy”, na który składają się albo wpływy, których w ogóle nie znamy, albo takie, o których wiemy, że istnieją, ale nie jesteśmy w stanie ich obserwować. Gdy już mamy skonstruowany jakiś model teoretyczny, musimy - na podstawie danych - estymować jego parametry. Powiedzmy, że wiadomo, iż kwota zapłacona za bułki zależy liniowo od liczby zakupionych bułek, przyjmując postać: $\mathrm{kwota}=\alpha \cdot$ bułki (całkiem realistyczny model). 
W tej sytuacji wystarczy nam jedna informacja. Jeśli wiemy, że za pięć bułek trzeba zapłacić półtora złotego, łatwo wyliczyć, że $\alpha=0.3 \frac{\mathrm{zł}}{\text { szt. }}$. Mamy też związek przyczynowy: każda bułka przyczynia się do zwiększenia kosztu o 30 groszy. Gdybyśmy mieli w modelu dwie lub więcej zmiennych, w celu liczbowego określenia zależności potrzebna byłaby analiza ceteris paribus. Jeśli cena mieszkania zależy od jego szerokości i długości: cena $=\alpha \cdot$ szerokość $+\beta \cdot$ długość, to $\mathrm{z}$ każdą jednostką szerokości (przy ustalonej długości) cena zwiększa się o $\alpha$, a z każdą jednostką długości (przy ustalonej szerokości) zwiększa się o $\beta$. To właśnie oznacza „,eteris paribus”: przy pozostałych zmiennych ustalonych.

Zazwyczaj nie mamy do czynienia z takimi łatwymi zależnościami. Już gdybyśmy chcieli stworzyć analogiczny model ilości zużytej farby drukarskiej od liczby wydrukowych stron, należałoby uwzględnić różną liczbę liter na każdej ze stron, na przykład dodając człon losowy. Wówczas nie wystarczyłaby nam jedna dana, a raczej - im więcej, tym lepiej.

Kolejne stopnie złożoności dochodzą, gdy przemieszczamy się w górę drabiny przewidywań. Najprostszym rodzajem problemów, według Heckmana [2000], są takie, w których chcemy przewidzieć rezultaty pewnej strategii, która była już stosowana $\mathrm{w}$ danej populacji. Wczoraj kupiliśmy w pewnym sklepie pięć bułek i chcemy przewidywać kwotę do zapłaty następnego dnia, gdy kupować będziemy siedem bułek. Kolejnym stopniem jest przewidywanie rezultatów strategii stosowanej $\mathrm{w}$ jednej populacji $\mathrm{w}$ zastosowaniu do populacji innej. Czyli, na podstawie należności zapłaconej za pięć bułek w pewnym sklepie, chcemy przewidzieć sumę należności, jaką będziemy musieli uiścić następnego dnia w sklepie na innej ulicy. Problem staje się bardziej złożony, gdyż musimy uwzględnić fakt, iż ceny w każdym ze sklepów mogą się różnić w sposób systematyczny. Wiadomo, że niektóre sklepy - w zależności od lokalizacji, obsługi oraz innych czynników - narzucają inną marżę na sprzedawane produkty. Ostatnim stopniem komplikacji jest przewidywanie efektów strategii, która nigdy dotąd nie była wdrażana. Zadanie, wydawałoby się, niemożliwe: niemniej, konieczne! Wyzwaniem staje się - na podstawie danych dotyczących innych rodzajów pieczywa - ocena kosztu surowców do wypieku i pracy piekarzy oraz marży danego sklepu. Z każdym kolejnym stopniem złożoności oczekiwanych przewidywań rośnie stopień komplikacji aparatu matematycznego, zaprzęganego w tym celu do pracy. Dorobek Jamesa Heckmana w zakresie rozwoju tych metod jest 
trwałym jego wkładem w teorię ekonometrii. Swego nazwiska jednakże użyczył jednej konkretnej metodzie, związanej nie tyle $\mathrm{z}$ trudnościami z modelami matematycznymi, ile raczej z niedoskonałością danych.

\section{Obciążenie próby}

Jak wspominaliśmy powyżej, po stworzeniu modelu ekonometrycznego musimy - na podstawie dostępnych danych - wyznaczyć konkretne wartości jego parametrów. Ocena tych parametrów może być jedynie tak dobra, jak dobre są dane... Stwierdzenie, wydawałoby się, bezdyskusyjne. A jednak Heckman pokazał, jak można obejść niedoskonałość danych, by uzyskać wyniki dokładniejsze, niż to na pozór możliwe.

Przyjrzyjmy się zatem pewnemu szczególnemu rodzajowi niedoskonałości danych, by lepiej przybliżyć istotę wkładu Heckmana.

Złośliwa być może wieść niesie, iż przeprowadzona niedawno telefoniczna ankieta wykazała, iż sto procent respondentów posiada telefon... Po upływie półsekundowej chwili zaskoczenia każdy z łatwością wskaże absurdalny błąd, jakim obciążone było to rzekome badanie. W większości przypadków jednakże uniknięcie obciążenia próby nie jest takie proste. Dotyczy to chociażby wszelkich dobrowolnych badań, jak choćby corocznie w Polsce przeprowadzanych Badań Budżetów Gospodarstw Domowych. Uczestnictwo w tym badaniu nie jest obligatoryjne, można zatem odmówić mozolnego codziennego wypełniania księgi przychodów i rozchodów. Można przypuszczać, że z większą częstotliwością zadania tego nie podejmą się ludzie bardzo zajęci: pracujący na dwa etaty czy matki kilkorga małych dzieci - co prowadzi do pewnego wypaczenia losowości próby.

Spośród mniej oczywistych i bardziej interesujących zjawisk wymienić można tzw. paradoks Berksona, czyli pojawianie się pozornych zależności na skutek obciążenia próby. Efekt ten prezentowany jest zwykle na przykładzie medycznym, posłużmy się jednak bardziej adekwatnym w dalszym ciągu wywodów rynkiem pracy. Załóżmy, że inteligencja i uroda są od siebie niezależne, przy czym ,inteligentnych" jest $80 \%$ osób, a „urodziwych” $-40 \%$ (w obu przypadkach w arbitralny sposób stawiamy pewną granicę). Załóżmy, że w naszym wymyślonym świecie, aby znaleźć zatrudnienie, trzeba dysponować co najmniej jednym z tych atutów. Oczywiście, bycie zarówno mądrym, jak i pięknym w znalezieniu pracy nie przeszkadza. Mamy więc następującą strukturę pracującej i niepracującej populacji: 
Tabela 1. Struktura pracujących i niepracujących

Nr 13(19)

z przykładu omawianego $\mathrm{w}$ tekście

\begin{tabular}{|l|c|c|}
\hline & inteligentni & nieinteligentni \\
\hline urodziwi & 32 & 8 \\
\hline nieurodziwi & 48 & 12 \\
\hline
\end{tabular}

Źródło: opracowanie własne.

gdzie szarym kolorem zaznaczone są osoby nieinteligentne i nieurodziwe, które pracy nie znalazły.

Przeprowadzamy teraz badanie wśród pracujacej populacji. Okazuje się, że wśród urodziwych inteligentni stanowią $80 \%$ $(32 /(32+8)=0.80)$, natomiast $\mathrm{w}$ całej pracującej populacji jest niemal $91 \% \quad((32+48) /(32+48+8) \approx 0.91)$ inteligentnych! Co sugeruje ujemną zależność pomiędzy urodą i inteligencją. Zależność pozorną, wynikającą tylko $\mathrm{z}$ pominięcia $\mathrm{w}$ badaniu niezbyt inteligentnych brzydali...

Wzbogaćmy teraz nasz wyimaginowany świat, w którym ponownie główną rolę $\mathrm{w}$ zatrudnieniu odgrywają inteligencja i uroda, ale tym razem każdy ma szansę podjąć jakąś pracę. Rodzaj tej pracy i płaca uzależnione są od atutów pracownika, choć w grę wchodzą również czynniki losowe - na przykład to, że potencjalny pracownik ma na imię tak samo, jak ukochany brat potencjalnego pracodawcy, albo pogoda $\mathrm{w}$ dniu składania oferty. W pierwszym kroku przyjmijmy jeszcze prostszą wersję, w której inteligencję mierzymy zwykłym ilorazem inteligencji, a pracodawcy nie biorą pod uwagę urody. Odbywają się targi pracy, na których każdemu mieszkańcowi złożona zostaje oferta. Powiedzmy, że wysokości tych proponowanych płac są takie, jak przedstawiono poniżej $\mathrm{w}$ tabeli (płace podajemy $\mathrm{w}$ jednostkach umownych):

Tabela 2. Dane dotyczące ilorazu inteligencji i proponowanej płacy dla populacji z przykładu omawianego w tekście

\begin{tabular}{|c|c|c|c|c|c|c|c|c|c|c|}
\hline IQ & 90 & 90 & 90 & 95 & 100 & 100 & 110 & 120 & 120 & 140 \\
\hline płaca & 110 & 80 & 90 & 95 & 120 & 100 & 140 & 150 & 120 & 170 \\
\hline
\end{tabular}

Źródło: opracowanie własne.

Jeśli chcielibyśmy się dowiedzieć, w jaki sposób dodatkowy punkt IQ przekłada się na wzrost proponowanej gaży, musielibyśmy wyznaczyć równanie regresji płacy względem punktów IQ: 


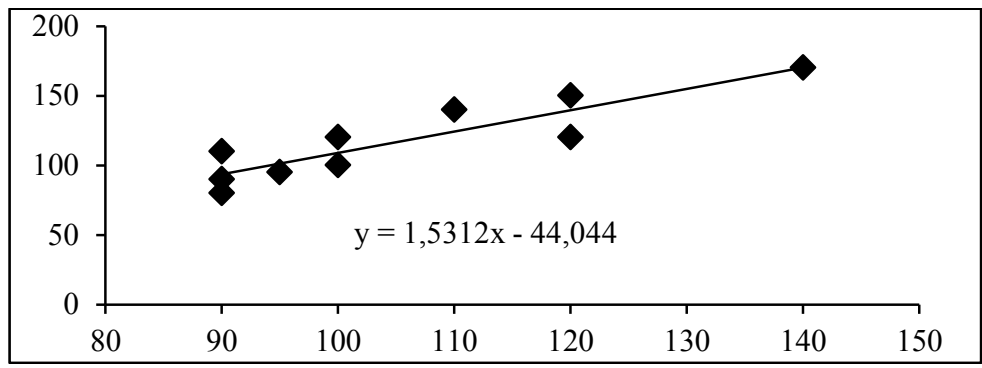

Rys. 1. Regresja liniowa proponowanej płacy względem ilorazu inteligencji dla populacji z przykładu omawianego w tekście

Źródło: opracowanie własne.

Otrzymany wynik interpretujemy tak, że każdy dodatkowy punkt IQ przekłada się, średnio rzecz biorąc, na nieco ponad 1.5 jednostki dodatkowego wynagrodzenia.

Nasz wymyślony światek jest jednakże światem o dobrej opiece socjalnej i zasiłek dla bezrobotnych wynosi w nim 100 jednostek. Można przypuszczać, że w takich warunkach osoby, którym oferuje się mniej niż 100 jednostek, nie podejmą pracy, woląc pozostawać na zasiłku:

Tabela 3. Dane dotyczące ilorazu inteligencji i proponowanej płacy dla populacji z przykładu omawianego w tekście. Szarym kolorem wyróżnione są osoby, które pracy nie podjęły.

\begin{tabular}{|c|c|c|c|c|c|c|c|c|c|c|}
\hline IQ & 90 & 90 & 90 & 95 & 100 & 100 & 110 & 120 & 120 & 140 \\
\hline płaca & 110 & 80 & 90 & 95 & 120 & 100 & 140 & 150 & 120 & 170 \\
\hline
\end{tabular}

Źródło: opracowanie własne.

Pula pracowników kurczy się zatem do 7 osób. Jeśli wyznaczymy dla nich regresję liniową wynagrodzenia względem ilorazu inteligencji, otrzymamy następujący obraz:

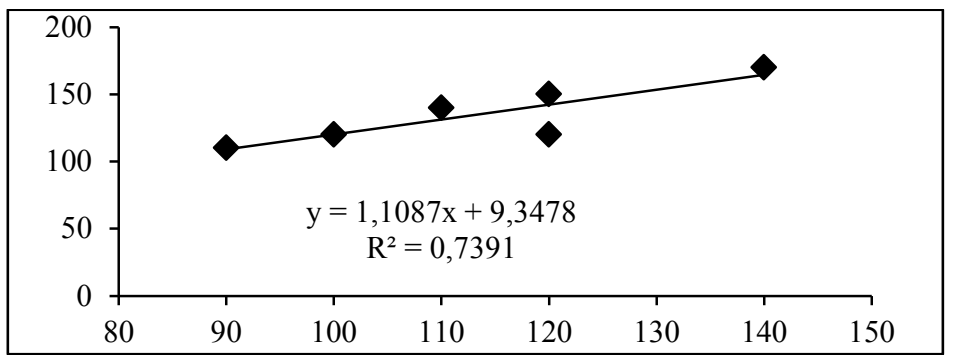

Rys. 2. Regresja liniowa proponowanej płacy względem ilorazu inteligencji dla populacji z przykładu omawianego $\mathrm{w}$ tekście, $\mathrm{z}$ wyłączeniem osób, które pracy nie podjęły

Źródło: opracowanie własne. 
Wniosek, który teraz wyciągamy, jest taki, że każdy dodatkowy punkt IQ przekłada się, średnio rzecz biorąc, na nieco powyżej 1.1 jednostki dodatkowego wynagrodzenia.

Ogólnie rzecz biorąc, nie uwzględniając faktu, iż zbyt niskie oferty nie zostały zaakceptowane i nie weszły do zestawu danych dotyczących osób pracujących, zaniżamy wpływ ilorazu inteligencji na szanse na rynku pracy.

Zarysowana powyżej sytuacja może być zapisana w bardziej formalny sposób za pomocą następujących równań:

$$
\begin{gathered}
\text { Proponowana Płaca }=\alpha_{0}+\alpha_{1} \cdot \mathrm{IQ}+\text { SkładnikLosowy, } \\
\text { Podjęcie Pracy }=\left\{\begin{array}{l}
1 \text { jeśli ProponowanaPłaca }>1000 \\
0 \text { jeśli ProponowanaPłaca } \leq 1000
\end{array}\right.
\end{gathered}
$$

Pierwsze $\mathrm{z}$ równań to standardowe równanie modelu regresji liniowej: zakładamy, że proponowana płaca wprost proporcjonalnie rośnie wraz z ilorazem inteligencji, ale dodatkowo pewną rolę odgrywają inne czynniki - np. wzrost, aparycja, ukończona uczelnia wszystkie one zostały zbiorczo wrzucone do worka oetykietowanego „składnik losowy”, powodujący, iż różne osoby z tym samym IQ mogą dostawać różne oferty. Drugie równanie określa, czy oferta jest do zaakceptowania, czyli, w naszym najprostszym przykładzie, czy przekracza gwarantowane świadczenie zapomogowe. Jeśli „ProponowanaPensja” przekracza 1000 jednostek, wówczas „PodjęciePracy” równe jest 1 .

Wyrażając „ProponowanąPłacę” tak, jak określa ją równanie pierwsze z (1a), otrzymujemy:

$$
\begin{gathered}
\text { ProponowanaPłaca }=\alpha_{0}+\alpha_{1} \cdot \mathrm{IQ}+\text { SkładnikLosowy, } \\
\text { PodjęciePracy }= \\
\left\{\begin{array}{l}
1 \text { jeśli }\left(\alpha_{0}-1000\right)+\alpha_{1} \cdot \mathrm{IQ}+\text { SkładnikLosowy }>0 \\
0 \text { jeśli }\left(\alpha_{0}-1000\right)+\alpha_{1} \cdot \mathrm{IQ}+\text { SkładnikLosowy } \leq 0
\end{array}\right.
\end{gathered}
$$

Warto podkreślić to, że „” z pierwszego i drugiego równania to ten sam składnik - dla określonej osoby jego wartość jest ustalona.

Estymacja modelu, czyli jak najlepsze „odgadywanie” wartości parametrów $\alpha$, opiera się na następującej zasadzie. Zadajemy pytanie: gdyby $\alpha_{0}$ było równe, przykładowo, 2.2, a $\alpha_{1} 5.3$, to jakie wówczas byłoby prawdopodobieństwo, że osoba o IQ równym 90 dostaje ofertę wartą 110, osobie z IQ równym 140 oferuje się pensję 170, i tak dalej (korzystamy z obserwacji). Prawdopodobieństwo - zamiast pewności 
- pojawia się tutaj na skutek występowania członu losowego. Dla wartości $\alpha_{0}$ i $\alpha_{1}$ wybranych na chybił-trafił, prawdopodobieństwo to będzie najpewniej bardzo małe. Wśród wszystkich możliwych kombiSTATYSTYCZNY nacji wartości tych parametrów szukamy takiej, dla której prawdopodobieństwo zaobserwowanego wyniku jest największe. Oczywiście, dysponujemy matematyczną procedurą znajdowania tego maksimum, nie musimy na ślepo wypróbowywać wszystkich możliwości (jest ich zresztą nieskończenie wiele).

W naszym przykładzie, jeśli uwzględnimy tylko pierwsze z równań - czyli bierzemy pod uwagę jedynie osoby, które zdecydowały się podjąć pracę - metoda maksymalizowania prawdopodobieństwa da nam wartości parametrów: $\alpha_{0}=9.3478$ i $\alpha_{1}=1.1087$, jak na rys. 2 powyżej.

Precyzyjniejsze oszacowanie da nam jednak uwzględnienie obydwu równań. W tym celu, prawdopodobieństwo danej oferty musimy przemnożyć przez prawdopodobieństwo, że oferta ta zostanie zaakceptowana. Oprócz pojawiającego się mnożenia dwóch prawdopodobieństw dodatkową komplikację stanowi fakt, iż prawdopodobieństwa te nie sa niezależne. Wynika to z faktu, że składniki losowe obu równań są skorelowane (a nawet identyczne).

To samo dzieje się również, jeśli uwzględnimy wpływ innych cech na proponowaną przez werbowników płacę. Spójrzmy na nieco bardziej skomplikowany model:

$$
\begin{gathered}
\text { ProponowanaPłaca }= \\
\alpha_{0}+\alpha_{1} \cdot \mathrm{IQ}+\alpha_{2} \cdot \text { uroda }+ \text { SkładnikLosowy }_{1},
\end{gathered}
$$

PodjęciePracy $=$

$\left\{1\right.$ jeśli $\beta_{0}+\beta_{1} \cdot$ pracowitość $+\beta_{2} \cdot$ PensjaWspółmałżonka + SkładnikLosowy $_{2}>0$ $\left\{0\right.$ jeśli $\beta_{0}+\beta_{1} \cdot$ pracowitość $+\beta_{2} \cdot$ PensjaWspółmałżonka + SkładnikLosowy $_{2} \leq 0$.

Powyższy model jest o wiele bardziej skomplikowany niż poprzedni, bo, po pierwsze, pojawia się w nim o wiele więcej zmiennych i parametrów, a po drugie, chęć do podjęcia pracy zależy od innych zmiennych niż proponowana płaca. Niemniej, wciąż można się spodziewać, że SkładnikLosowy ${ }_{1}$ i SkładnikLosowy ${ }_{2}$ - choć już nieidentyczne - będą skorelowane. I ponownie ta zależność składników losowych wprowadza dodatkowy stopień złożoności numerycznej.

$\mathrm{W}$ jeszcze nie tak dawnych czasach, gdy moce obliczeniowe najlepszych komputerów były skromne, a dostęp do nich limitowany, pojawiające się złożoności obliczeniowe częstokroć stanowiły przeszkodę nie do sforsowania, a najlepsze umysły poświęcały swój krea- 
tywny trud, by jakąś sprytną sztuczką analityczną raczej je wyminąć niż obalić, ułatwiając maszynie pracę. Opracowana przez Heckmana metoda miała na celu właśnie uproszczenie obliczeń w tego typu zagadnieniach, z częścią wartości nieobserwowalnych.

Zamiast za jednym zamachem rozwiązywać model składający się $\mathrm{z}$ dwóch równań, podchodzimy do sprawy dwuetapowo. Drugie z równań modelu (2), traktowane samodzielnie, stanowi tak zwany model probitowy. W pierwszym etapie zatem, dysponując pewnym zestawem danym, zawierającym informacje o pracowitości, pensji współmałżonka oraz o ostatecznej decyzji (pracować/nie pracować), oceniamy skłonność osoby o zadanej charakterystyce do podjęcia pracy. Sposób oceny tego prawdopodobieństwa jest standardem wśród metod statystycznych i opiera się na takim wyborze wartości parametrów, by maksymalizować wiarygodność otrzymania wyniku, który faktycznie został zaobserwowany.

Warto może wspomnieć, że metoda ta, nazywana metoda największej wiarygodności, swoje filozoficzne podstawy dzieli z innymi dziedzinami nauk, w szczególności z fizyką - dzieli też z nimi zasadnicze wątpliwości. W termodynamice na przykład szermuje się często argumentem, iż makroskopowy stan układu musi być najbardziej prawdopodobną realizacją stanu mikroskopowego. O ile jednakże zasadniczo dysponujemy wielką mnogością pojemników z gazem i stanowisko takie może być uzasadnianie interpretacją częstościową prawdopodobieństwa, o tyle - na przykład - populacją Polaków dysponujemy tylko jedną jedyną. Jaka gwarancja, że cała ta zbiorowość zrealizuje opcję o prawdopodobieństwie, powiedzmy, raczej 0.5 niż 0.05 ? Jakkolwiek byśmy ją rozumieli, faktem jest, że metoda się sprawdza.

Wróćmy do dwustopniowej metody Heckmana. Na podstawie drugiego z równań modelu (2) oszacowaliśmy prawdopodobieństwa podjęcia pracy przez osoby o zadanych charakterystykach. W tym momencie „udajemy” jakby, że nie wiemy, czy ktoś pracuje czy nie: tak naprawdę, skoro wiemy, że pan X podjął pracę, to prawdopodobieństwo takiego zdarzenia wynosi dokładnie jeden! Ten związek pomiędzy wiedzą a prawdopodobieństwem podkreśla matematyk $\mathrm{i}$ ekonomista, Amir Aczel, w tytule jednej ze swoich popularnych książek: Prawdopodobieństwo $=1$ [Aczel 2000]. Tytuł ten jest odpowiedzią na pytanie: jakie jest prawdopodobieństwo tego, że we Wszechświecie wyewoluuje życie? Skoro wiemy, że żyjemy, odpowiedź może być tylko jedna... Tak samo, skoro wiemy, kto podjął, a kto nie podjął prace, prawdopodobieństwa równe są albo 1 albo 0 . Na chwilę 
spuszczamy jednak zasłonę niewiedzy i wyliczamy te prawdopodobieństwa. Okazuje się, że te wartości ,aprioryczne” mogą się znacząco różnić dla różnych osób o tym samym finalnym wyniku. Jedna osoba STATYSTYCZNY jest tak niesamowicie pracowita, że prawdopodobieństwo wyniosło dla niej 0.999 i nawet bez sprawdzania mieliśmy niemal pewność, że podjęła pracę. Inna osoba pracowitością nie grzeszy, a jego żona ma przyzwoite dochody - i prawdopodobieństwo otrzymaliśmy 0.7 . Niemniej, albo oferta pracy była tak kusząca, albo akurat dzień sprzyjał takiej decyzji - w każdym razie i ta osoba zaakceptowała ofertę pracy, pomimo znacznie mniejszej uprzedniej predyspozycji.

Dysponując zestawem prawdopodobieństw dla każdej osoby, która pracę podjęła, traktujemy te wartości jako dodatkowe charakterystyki, które dodajemy do pierwszego z równań modelu (2):

$$
\begin{gathered}
\text { ProponowanaPłaca }= \\
\alpha_{0}+\alpha_{1} \cdot \mathrm{IQ}+\alpha_{2} \cdot \begin{array}{l}
\text { uroda }+\alpha_{3} \cdot \text { prawdopodobieństwo }+ \\
\text { SkładnikLosowy }
\end{array} .
\end{gathered}
$$

I znowu otrzymujemy standardową postać modelu, który możemy estymować znanymi statystycznymi metodami.

Na pierwszy rzut oka wygląda prosto; zbyt prosto, by było prawdziwe. I faktycznie, prawdziwe nie jest, przynajmniej w tym nadmiernie uproszczonym zapisie powyżej. Ponieważ w modelu (2) składniki losowe $\mathrm{z}$ równania pierwszego i drugiego są ze sobą skorelowane, parametr $\alpha_{3}$ zawiera $\mathrm{w}$ sobie miarę wzajemnego splatania tych składników losowych; z tego samego powodu składnik losowy w modelu (3) otrzymał kolejny numerek, gdyż nie jest tożsamy z żadnym poprzednim członem losowym. Co gorsza, może się okazać, iż jest bardzo „nienormalny” - czego statystycy nie lubią.

Nie wikłając się dalej w zbyt techniczne i skomplikowane szczegóły, pozostaje nam tylko zaufać, że dokładny przepis Heckmana na rozwiązywanie modeli typu (2), z częścią wartości nieobserwowalnych, został gruntownie przebadany pod każdym względem i udowodnił swoją użyteczność.

Faktem jest, iż nie uchronił się też przed krytyką.

Podejście Heckmana jest przybliżeniem, zatem z definicji musi być mniej dokładne niż rozwiązanie ścisłe. Wskazywano na różne niedostatki tej metody - jednakże równolegle opracowywano również sposoby jej ulepszenia (np. [Lee 1982; Little, Rubin 1987; Puhani 2000]). Wydaje się, iż wraz z rozwojem metod numerycznych umożliwiających rozwiązywanie dwurównaniowego modelu w sposób ścisły, 
potrzeba korzystania z przybliżenia - nawet tak interesującego i rozbudowanego teoretycznie - będzie systematycznie malała. W końcu sam jego autor stwierdził skromnie, iż wyniki otrzymane za pomoca jego przybliżenia są tylko „dobrym punktem wyjścia” do obliczeń ścisłych [Heckman 1979]: gdy za pomocą komputera próbujemy znaleźć wartości maksymalizujące pewne wyrażenie (jak w metodzie największej wiarygodności), musimy mu „podpowiedzieć”, w jakich okolicach wartości tych ma szukać.

Jednak nawet jeśli metoda Heckmana miałaby odejść do lamusa, nie można jej odmówić znaczącej roli w historii badań ekonometrycznych i w rozwoju tej dziedziny nauki.

\section{Co z tego wynika - dyskryminacja rasowa}

Narzędzia, których autorem bądź współautorem był Heckman, posłużyły wielokrotnie do analizowania rynku pracy. Dzięki nim okazało się, między innymi, iż kursy mające podnosić pracownicze kompetencje są wysoce nieefektywne i służą głównie jako swego rodzaju biura pośrednictwa pracy [Heckman i in. 1999]. Pozory efektywności stwarzane są przez fakt, że z programów takich korzystają zwykle osoby, które właśnie straciły pracę. Nic dziwnego zatem, że - jeśli uda im się znaleźć jakiekolwiek zatrudnienie po odbytym kursie - odnotowywany jest znaczący wzrost zarobków, choć niekoniecznie kompetencji zawodowych. Inną interesującą sugestią jest to, iż różnica w nierównościach zarobkowych pomiędzy Stanami Zjednoczonymi a Europą miałaby być $\mathrm{w}$ dużej mierze powodowana wyższymi zasiłkami oraz silniejszymi związkami zawodowymi na kontynencie europejskim [Heckman 2001]. Te dwa czynniki powodują bowiem, iż większa niż w USA część słabo wykwalifikowanej siły roboczej pozostaje niezatrudniona.

Ale dwiema kwestiami społecznymi, z którymi w głównej mierze - dla jednych na dobre, dla innych na złe - związane jest nazwisko Heckmana, są ekonomiczny status Afroamerykanów oraz efekty edukacji w dzieciństwie.

Wspominaliśmy już, iż jako młody człowiek Heckman doświadczył w działaniu tak zwanych praw Jima Crowa, czyli segregacji rasowej $\mathrm{w}$ południowych stanach. Urodzony jednak na Północy, ze zdziwieniem przyjął - będąc kilkuletnim dzieckiem - że najlepsze miejsca $\mathrm{w}$ autobusie, czyli w pobliżu tylnej panoramicznej szyby, zarezerwowane są dla obywateli o ciemniejszym kolorze skóry. W szkole ciemnoskóre osoby widywał tylko przelotnie, nie w charakterze uczniów czy nauczycieli, ale pracowników pomocniczych. Po 
szkole, w parku, siadał na ławkach przeznaczonych dla białych i bawił się przy wydzielonych dla nich fontannach. Najwyraźniej ten rodzaj segregacji nie przypadł mu do gustu, gdyż w nieco późniejszym już STATYSTYCZNY wieku zdecydował się na złamanie tabu. Wyruszył bowiem w podróż po południowych stanach w towarzystwie zaprzyjaźnionego Nigeryjczyka. Był rok 1963. Osiem lat już minęło od chwili, gdy niepokorna czarnoskóra Rosa Parks odmówiła ustąpienia miejsca w autobusie białemu mężczyźnie. Niecałe pół roku wcześniej Martin Luther King wraz $\mathrm{z}$ ponad dwustu tysiącami ludzi maszerował na Waszyngton $\mathrm{i}$ miał swoje wielkie marzenie. Niemniej, szczęki segregacji były wciąż kurczowo zaciśnięte, a w atmosferze unosił się strach. Bali się koledzy, gdy w Birmingham Heckman postanowił zamieszkać wraz z przyjacielem w budynku dla ciemnoskórych. Bali się policjanci, zmuszając młodych ludzi do zatrzymania się w odrębnych hotelach następnego dnia. Czarni radośnie machali do przejeżdżającego samochodu $\mathrm{z}$ różnokolorową parą $\mathrm{w}$ środku, ale $\mathrm{w}$ sklepach musieli zajmować osobne kolejki.

Była to jedna z ostatnich chwil, by doświadczyć w Stanach Zjednoczonych systemowej dyskryminacji. Już w lipcu następnego roku przyjęta została ustawa o prawach obywatelskich zakazująca segregacji rasowej. Za nią poszły liczne akcje afirmatywne, mające zadośćuczynić minionej niesprawiedliwości i wyrównać szanse Afroamerykanów.

Mając na względzie doświadczenia z młodości, zrozumiałym wydaje się zainteresowanie Heckmana badaniem zmian w socjoekonomicznym statusie ciemnoskórych mieszkańców USA. Jak sam przyznaje [Klein, Daza 2013], zabierał się do tego zadania sadząc, iż rezultaty potwierdzą przewidywania chicagowskich uczonych o kluczowej roli rynku w emancypacji tej części ludności. Zgodnie z tą tezą, ani działania legislacyjne z roku 1964, ani późniejsze akcje „wyrównujące" nie miały większego wpływu na położenie Czarnych. Uczciwość badawcza nie pozwoliła jednakże Heckmanowi zanegować tego, co się ewidentnie z danych wyłoniło: zmiana prawna z 1964 r. miała zasadniczy wpływ na sytuację na rynku pracy i poziom średnich zarobków. Najwyraźniej gospodarka potrzebowała dodatkowego bodźca: to, co ciemnoskórzy pracownicy oferowali na rynku pracy, samo w sobie - wbrew logice rynkowej, wedle której każdy powinien zostać oceniony rzetelnie, bez uprzedzeń rasowych - nie wystarczyło, by uczynić z nich pełnowartościowych (i rzetelnie wartościowanych) uczestników giełdy pracy. Rezultaty tych badań opublikowane zostały w 1989 r. [Heckman i Payner 1989] i ze względu na to, z jakiego środowiska akademickiego wyszły, stanowiły akt intelektualnej odwagi. 
„Niektórzy z moich kolegów odnieśli się do tych wyników wrogo", powiedział w wywiadzie Heckman. „Niektórzy wciąż się tak odnoszą". Sam Heckman uznaje te prace za największe swoje naukowe osiągnięcie (a nie prace teoretyczne, wymienione w werdykcie Komitetu Noblowskiego) [Liesman 2000]. Z drugiej strony, dalsze badania wykazały, iż późniejsze akcje afirmatywne nie odniosły oczekiwanego skutku w podnoszeniu statusu Afroamerykanów [Heckman 2011]. Taka postawa naukowa, która - wbrew ideologii i poprawności politycznej - stoi twardo zawsze po stronie faktów i prawdy, mogłaby stanowić przykład dla wszystkich doktrynerów świata.

Kwestia rasowa towarzyszyła Heckmanowi również w późniejszych badaniach, splatając się z pracami teoretycznymi nad obciążeniem próby. Optymistyczne wyniki, publikowane również w bardziej popularnych opracowaniach, wskazują na to, iż przepaść pomiędzy dochodami białej i czarnej części ludności systematycznie się zmniejsza. Niestety, zauważa Heckman, obraz taki wyłania się jedynie, gdy uwzględniamy faktycznie pracującą część ludności. Jeśli jednakże wziąć pod uwagę znacznie większą stopę bezrobocia wśród ciemnoskórej ludności, okazuje się, iż rezultat jest znacznie mniej korzystny [Heckman i in. 2000].

Wniosek, jaki wyciąga Heckman ze swoich własnych oraz innych badań jest następujący. Ani sam rynek nie może posłużyć do wyciągnięcia części społeczeństwa ze stanu „odziedziczonego” ubóstwa, ani odgórne akcje rządowe. W tym miejscu problem wyrównywania szans dla mniejszości zazębia się z drugim konikiem Heckmana: efektami wczesnej edukacji.

\section{Edukacja}

W 1994 r. ukazała się książka Richarda J. Herrnsteina i Charlesa Murray'a zatytułowana The Bell Curve (Krzywa dzwonowa) [Herrnstein, Murray 1994]. Jak na tak niewinny tytuł publikacja wywołała ogromne poruszenie i wiele kontrowersji. Dotyczyła bowiem niezwykle newralgicznego tematu: ilorazu inteligencji.

Sama koncepcja ilorazu inteligencji oraz testy mające go mierzyć są łatwym celem ataków, zarówno z punktu widzenia metodyki, jak i poprawności politycznej. Obrońcom testów trudno jest wyjaśnić fakt, iż średni iloraz inteligencji całej populacji systematycznie rośnie z dekady na dekadę (tzw. efekt Flynna [Flynn 1987]). Inni krytycy podnoszą zarzut kulturowego obciążenia tych testów. Z innej strony zwolennicy IQ zarzucani są koncepcjami alternatywnych ilorazów inteligencji: emocjonalnej, społecznej, ekologicznej... 
Najbardziej minimalistyczna definicja ilorazu inteligencji stanowi, iż IQ jest tym, co mierzą testy na inteligencję... Definicja niekontrowersyjna, aczkolwiek mało przydatna i być może myląca - jako że STATYSTYCZNY wykorzystuje pojęcie ,inteligencji” egzystujące w języku potocznym i powszechnie z czymś kojarzone. Herrnstein i Murray postanowili „zoperacjonalizować” tę definicję, pokazując, iż wyniki testów na inteligencję przeprowadzanych $\mathrm{w}$ dzieciństwie przekładają się na osiągnięcia i potknięcia życiowe: karalność, wysokość zarobków, nieplanowane ciąże i, ogólnie, status socjoekonomiczny. To, samo w sobie, być może nie wywołałoby takiej burzy, gdyby autorzy nie dorzucili bomby: inteligencja jest zdeterminowana genetycznie. Co więcej, istnieją rasowe różnice $\mathrm{w}$ inteligencji, również powodowane czynnikami genetycznymi. Twierdzenia te wzbudziły niepokój w narodzie self-made-menów i doczepiły autorom łatkę rasistów, przywołując złowrogie echo słów sędziego Olivera Wendella Holmesa uzasadniającego na początku XX w. eugeniczny wyrok sterylizacji: „Trzy pokolenia imbecyli wystarczą" [Black 2004].

Heckman nie uznał jednakże dyktatu poprawności politycznej, nie zezwalającej w ogóle na poruszanie pewnych tematów. Książkę The Bell Curve uznał za bardzo istotną, podnoszącą ważkie kwestie. Dała ona, wedle Heckmana, asumpt do potrzebnej dyskusji na temat roli edukacji we wczesnym dzieciństwie. Nie uważa, by dociekanie prawdy naukowej mogło być równoznaczne $\mathrm{z}$ wdrażaniem niepożądanych społecznie rozwiązań politycznych. Niemniej, nie zgadza się z głównymi tezami autorów, wytykając im liczne błędy w metodyce badań. Przede wszystkim wskazuje, iż dzieci badane były w wieku lat 14 - a trudno uznać, iż do tego wieku nie uległy one żadnym środowiskowym wpływom związanym z byciem wychowywanym w takiej a nie innej rodzinie.

Odziedziczalność nie tylko inteligencji, lecz także innych cech osobowościowych, jest od dawna kwestią wielce kontrowersyjną i mało który badacz potrafi uchronić się od wyciągania wniosków odnośnie ,jest”, kierując się „chciałbym, by było”. Co więcej, niektórzy uważają, że jeśli stan faktyczny jest nie do pogodzenia $\mathrm{z}$ ideałami demokratycznych społeczeństw, nie należy takich badań przeprowadzać. Zapewne to te narosłe wokół tematu emocje zaciemniają obraz. $\mathrm{Z}$ jednej strony mamy przykłady niesamowitych wręcz koincydencji pomiędzy bliźniętami jednojajowymi, wychowywanymi przez zupełnie odmienne rodziny, a nawet w różnych kulturach [Bouchard i in. 1990]. Z drugiej strony, mamy przykład identycznych bliźniaków, którzy odziedziczyli wadliwy gen powodujący dziedziczną neurofibromatozę typu 1. U Adama schorzenie przejawia się w postaci znie- 
kształconej twarzy. U ponadprzeciętnie przystojnego Neila natomiast - zanikami pamięci i napadami padaczkowymi [Moalem 2014]. Stosunkowo młoda nauka, epigenetyka, daje nam zarówno nadzieję, jak i nakłada świadomość ogromnej odpowiedzialności: otóż okazuje się, że doświadczenia wczesnego dzieciństwa, a nawet jeszcze wewnątrzmaciczne, mogą wywierać kluczowy wpływ na całe dalsze życie, a nawet życie kolejnych pokoleń [Holliday 2006]. Z analiz Heckmana oraz innych wynika jednakże, że zasadniczym elementem wcale nie jest śrubowanie wyników testów IQ naszych pociech za pomocą zabawek edukacyjnych typu „Baby Einstein”.

Jako jeden z pierwszych na szlak przewidywania przyszłych osiągnięć dzieci wyruszył Lewis Terman, psycholog z Uniwersytetu Stanford, w 1921 r. Na podstawie testów inteligencji wyselekcjonował on grupę potencjalnych ,geniuszy”, nazywanych później Termitami. Śledząc ich dalsze losy, do dorosłości, zauważył dwie rzeczy. Po pierwsze, jedynych dwóch noblistów z badanych przez niego dzieci nie zakwalifikowało się do pierwotnej grupy „geniuszy” (zbyt niskie IQ, poniżej 140), natomiast ci z najwyższymi wynikami na teście wcale nie radzili sobie lepiej niż osoby ze środka grupy [Terman (red.) 1959]. Ogólnie oszacowano, iż powyżej 120 dodatkowe punkty IQ nie przekładają się na większy życiowy sukces.

Drugim kluczowym badaniem, jednym z najsłynniejszych w całej historii psychologii eksperymentalnej, był „test Marschmallow” Waltera Mischela z lat 60. i 70. ubiegłego wieku [Mischel i in. 1972]. Kilkuletnie dzieci stawiane w nim były przed następującym dylematem. Przed maluchem, na stoliku, kładziono ulubiony przez amerykańskie dzieci przysmak (w różnych wersjach eksperymentu były to łakocie różnego rodzaju; nazwa eksperymentu uwieczniła jeden z nich), po czym eksperymentator wychodził z pomieszczenia. Dziecko mogło albo natychmiast zjeść słodycze, albo poczekać na powrót eksperymentatora do pokoju - w takim przypadku miały obiecane podwojenie nagrody. Eksperyment dotyczył więc umiejętności odraczania natychmiastowej gratyfikacji, w której - jak wiadomo - również dorośli ludzie nie zawsze celują. Odnajdując badane dzieci wiele lat później, Mischel wykrył zupełnie przez siebie samego nieoczekiwaną zależność. Okazało się bowiem, iż umiejętność samokontroli była bardzo silnym wyznacznikiem przyszłego sukcesu w dorosłym życiu! [Mischel, Ayduk 2004].

Wiele wysiłku włożył Heckman, by w sposób matematycznie poprawny oddzielać w analizach ekonometrycznych wpływ, z jednej strony, zdolności poznawczych (IQ) i niepoznawczych, jak siła woli 
czy ekstrawersja, z drugiej. Wyniki sporej liczby drobiazgowych ana-

liz wskazują na ograniczoną (choć do pewnego stopnia niewątpliwą) STATYSTYCZNY

rolę zdolności poznawczych - co sugerowały już badania Termite'a oraz znacznie większą, niż do tej pory sądzono, wagę zdolności niepoznawczych, w szczególności wytrwatości [Heckman, Rubinstein 2001; Heckman 2011; Almlund i in. 2011]. Heckman nie pozwala, by badania te pozostały jedynie akademicką ciekawostką. $Z$ dużą energią rozpowszechnia zdobytą wiedzę wśród decydentów, mających wpływ na kształt polityki edukacyjnej. Przykładowo, wskazuje na fakt, iż program GED - mający umożliwić zdobycie dyplomu ukończenia (odpowiednika polskiej) szkoły średniej osobom, które z różnych powodów musiały zrezygnować z uczęszczania do szkoły - jest skuteczny jedynie w kilku procentach. Po prostu ci, którzy nie mieli dość wytrwałości, by podążać zwykłym trybem nauczania, nawet po uzyskaniu certyfikatu, choćby $\mathrm{z}$ najlepszym wynikiem, nie będą $\mathrm{w}$ stanie podjąć i utrzymać pracy. W zamian, wedle Heckmana, warto byłoby promować inicjatywy typu Przedszkolny Program Perry'ego [Schweinhart, Weikart 1998]. O jego relatywnym - w porównaniu do GED - sukcesie decydować miały dwa czynniki: młodszy wiek uczestników oraz nastawienie na budowanie zdolności pozapoznawczych zamiast poznawczych. Heckman zainspirował również wiele bardziej oddolnych inicjatyw. Współautorka niektórych z jego prac, psycholog Angela Lee Duckworth, zrezygnowała z prestiżowej pracy w biznesie, by nauczać nastolatki w publicznej szkole Nowego Jorku - koncentrując się nie tylko na pogłębianiu ich wiedzy w konkretnych obszarach objętych testami kompetencyjnymi, lecz także na kształtowaniu charakterów.

Zagadnienia edukacji wiążą się ściśle z kwestią społecznego upośledzenia mniejszości rasowych. Skoro akcje afirmatywne nie dają pożądanych rezultatów, a działania edukacyjne kierowane do dorosłych są stosunkowo nieskuteczne, wyrównywanie szans należałoby rozpoczynać na wcześniejszym etapie kształtowania postaw dzieci i skupiać się na postawach właśnie, a nie numerycznych wynikach testów. Potrwać może nim ta nowa wiedza zostanie zaakceptowana przez ogół pedagogów. Budowanie motywacji i charakteru dziecka jest bardzo delikatnym zadaniem, wymagającym więcej trudu, wyczucia i delikatności niż wtłaczanie do głów liczb i faktów.

Zapewne zawsze należy dążyć do poznania prawdy, jakakolwiek by ona nie była - nawet politycznie niepoprawna. Nie ulega jednakże wątpliwości, po której stronie leżą uczucia większości osób wychowanych w kulturze „możliwości” i kształtowania własnego życia. Jeden ze 
współautorów The Bell Curve, Charles Murray, stwierdza bowiem: „Jeśli nie zaczniemy mówić głośno, że studia wyższe stanowią zbyt trudne intelektualnie wyzwanie dla większości młodych ludzi, będziemy nadal podsycać w kolejnych pokoleniach idiotycznie nierealistyczne oczekiwania" (cyt. za: [Tough 2014, s. 278]). Z drugiej strony, Angela Duckworth utrzymuje, iż „Przyzwyczajenie i charakter to w zasadzie jedno i to samo. [...] Jedne [dzieci] mają dobre nawyki, inne mają złe nawyki. [...] Chcecie, by wasi uczniowie, opuszczając gimnazjum, mieli już zagięcia [czyli nawyki], które w przyszłości pozwolą im odnieść sukces" (cyt. za: [Tough 2014, s. 169]).

\section{Bodźce}

James Heckman słynie z niespożytej energii. Z jednej strony przejawia się to $\mathrm{w}$ sposobie bycia, energicznym stylu prowadzeniu wykładów czy rozmowy. $Z$ drugiej - niesamowitą produktywnością naukową, graniczącą, wedle niektórych kolegów po fachu, $\mathrm{z}$ pracoholizmem. Sam zaprzecza jednakże temu pomówieniu, twierdząc, iż jest szczęściarzem, mogąc $\mathrm{w}$ ramach pracy robić to, co jest dla niego największą przyjemnością: oddawać się intelektualnemu rozwojowi [Clement 2005].

A oddaje mu się z nieomal religijną żarliwością, którą to analogię sam przeprowadza. Urodzony w rodzinie fundamentalistycznych protestantów, do wieku 15 lat służył do mszy w kościele, kiedy to zdecydował, że nie odpowiada mu atmosfera nietolerancji światopoglądowej oraz dogmatyzmu. „Nie byłem w stanie zaakceptować autorytetu po prostu dlatego, że jest autorytetem" [Heckman 2009, s. 302]. Szczęśliwie, w tym samym czasie spotkał osobę, której idee zdołały zapełnić pustą przestrzeń pozostawioną $\mathrm{w}$ jego wnętrzu przez utratę wiary religijnej i poczucia wspólnoty wyznaniowej. Osobą tą był wspominany uprzednio Frank Oppenheimer, który zaszczepił młodemu człowiekowi miłość do nauki: „możliwość przewidywania na podstawie praw fizycznych zjawisk empirycznych jest wspaniałą alternatywą dla religii i autorytetu" [Heckman 2009, s. 303]. W wypowiedziach Heckmana nie czuje się jednakże nuworyszowskiego prozelityzmu czy agresji do odrzuconej wiary. Raczej wydaje się świadom, iż zarówno religia, jak i nauka są pewnymi sposobami poszukiwania prawdy i zaprowadzania ładu w świecie, a każdy człowiek wybiera sposób, który lepiej odpowiada jego temperamentowi. Bo i w nauce spotkać można „wyznawców”, czego krytyczny umysł Heckmana nigdy przyjąć nie mógł: „Choć bardzo ceniłem sobie kontakty z [Mil- 
tonem] Friedmanem [...], nie podobało mi się bezkrytyczne, niemal religijne oddanie, z jakim do jego pomysłów podchodziło wielu moich kolegów" [Heckman 2009, s. 307]. Zasadniczym rysem umysłowości STATYSTYCZNY Heckmana wydaje się zatem krytycyzm i ścisła metodologia nauk empirycznych - a jednocześnie pokora odnośnie możliwości ludzkiego poznania: „Wierzę w prowizoryczną prawdę. Nie w absolutną niezmienną prawdę; ale mam poczucie, że gdzieś tam istnieje rzeczywistość, czekająca na zrozumienie za pomocą danych i modeli” [Heckman 2010a, s. 550].

Jak widzieliśmy na przykładzie badań dotyczących ilorazu inteligencji i wpływu edukacji, dążenie do odkrycia tej prawdy jest $u$ Heckmana bardzo silne i zdecydowanie przewyższa ewentualny lęk przed niepoprawnością polityczną czy sprzeciwem wobec kolegów z uczelni. „To, w jaki sposób Heckman pozwala, by prawda przeważała nad ideologią, czyni z niego idealnego naukowca i odróżnia go od innych luminarzy-noblistów z Uniwersytetu w Chicago, jak Milton Friedman i George Stigler, którzy, pomimo bardzo istotnego wkładu do ekonomii, kierowali się niekiedy sztywnymi zasadami konserwatywnej ideologii" [Donohue 2002, s. 29], stwierdza John J. Donohue, ekonomista z Uniwersytetu Stanforda.

Surowość Heckmana odnośnie standardów naukowości nie oszczędza jego własnych kolegów po fachu. Zapytany, czy ekonomia w ogóle jest nauką, Heckman odpowiada zdecydowanym „nie”. „Chciałbym, by była i sądzę, że istnieje wśród nas grupa mająca wizję ekonomii jako nauki. Mam nadzieję, że ekonomia stanie się nauką. [...[ Ekonomia formalna rozwiązuje problemy, daje spójne logicznie rozwiązania. Szanuję takie podejście, gdyż jest ono dobrze zdefiniowane intelektualnie. Wyostrza myślenie, może nakierowywać prace empiryczne i sugerować hipotezy. Teoria ekonomiczna jest bardzo ważna. Ale, po części jest jak filozofia, po części jak matematyka. Jest bardzo interesująca $z$ intelektualnego punktu widzenia i pouczająca, ale nie jest nauką, bo nie ma związku z danymi. Dopiero kiedy stymuluje prace empiryczne, wtedy staje się nauką. Z drugiej strony, niektórzy mający kontakt $\mathrm{z}$ danymi, traktują empiryczne analizy jako efektowne ćwiczenie, produkując coś błyskotliwego i iskrzącego się, ale nieposiadającego trwałej wartości. To nie nauka. To dziennikarstwo" [Heckman 2010a, s. 572-574].

Wrażliwość społeczna i ogólnie sympatyczne wrażenie, jakie się odnosi, czytając wypowiedzi Heckmana, na pierwszy rzut oka niezbyt pasują do - przynajmniej stereotypowego - wizerunku ekonomisty szkoły chicagowskiej. Swój stosunek do tej ostatniej uczony podsu- 


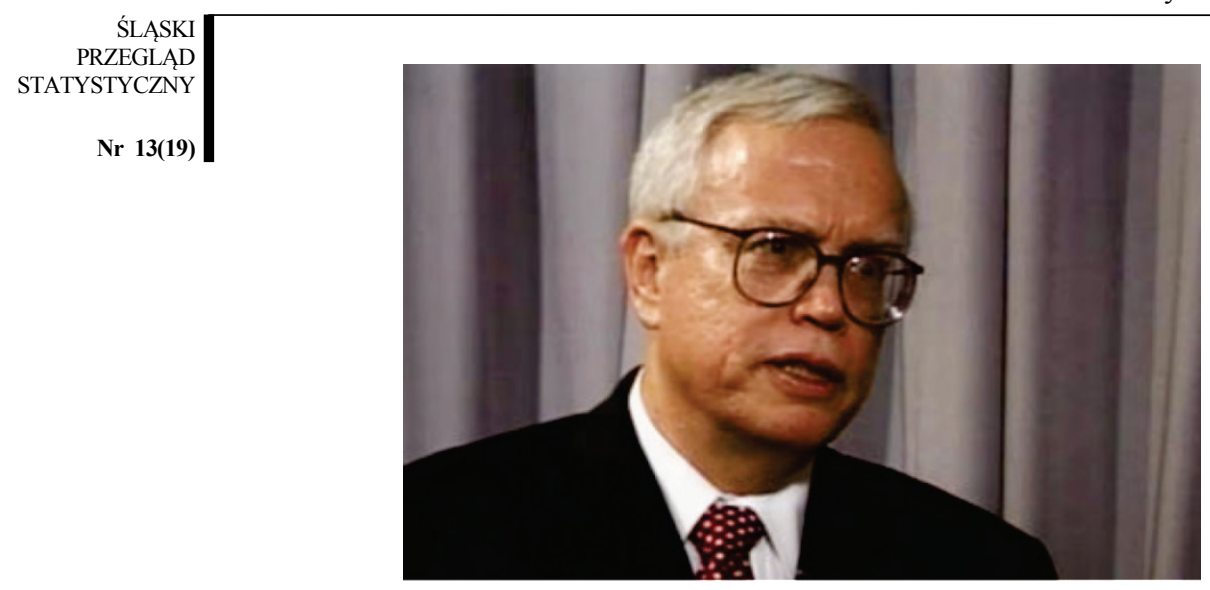

Rys. 3. James J. Heckman podczas wywiadu dla Nobelprize.org (2000)

Źródło: Nobelprize.org. http://www.nobelprize.org/nobel_prizes/economic-sciences/ laureates/2000/heckman-photo.html

mowuje następująco: „To, co wziąłem z Chicago, to nie jakieś twarde stanowisko w kwestii dochodów minimalnych ani nic z tych rzeczy, ale zrozumienie, że bodźce odgrywają ważną rolę" [Heckman 2013, s. 5]. Przy czym „bodziec” rozumiany jest tutaj raczej w rynkowym znaczeniu. W pewnym miejscu bardzo dosadnie ilustruje swoją wizję: „Gdybym mógł subsydiować morderstwa dzieci i gdybym zaoferował wystarczająco wysoką kwotę nie sądzę, bym miał specjalny problem z podażą morderców" [Heckman 2010b, s. 3]. Z drugiej strony, przykład samego Heckmana wydaje się wskazywać na to, iż w życiu przynajmniej niektórych ludzi to pozarynkowe motywacje są najsilniejszymi motorami ich działań. Dla samego uczonego jest to dążenie do poznawania prawdy. Bo chyba nie kwota otrzymana wraz z medalem opatrzonym wizerunkiem Alfreda Nobla i rogami obfitości...

\section{Literatura}

Aczel A., Prawdopodobieństwo = 1, Zysk i S-ka, Poznan 2000.

Akerlof G.A., Shiller R.J., Zwierzęce instynkty, Studio Emka, 2011.

Almlund M., Duckworth A. L., Heckman J. J., Kautz T. D., Personality psychology and economics, 16822, National Bureau of Economic Research, 2011.

Ariely D., Zalety irracjonalności, Wydawnictwo Dolnośląskie, 2010.

Becker G., Irrational behavior and economic theory, "The Journal of Political Economy" 1962, Vol. 70, 1-13.

Bettelheim B., A Good Enough Parent, Alfred A. Knopf, Inc, USA, 1987.

Black E., Wojna przeciw słabym, Muza, Warszawa 2004.

Bouchard T.J., Lykken D.T., McGue M., Segal N.L., Tellegen A., Sources of human psychological differences: the Minnesota Study of Twins Reared Apart, „Science” 1990, Vol. 250, s. 223-228. 
Clement D., "Nobel prize-winning economist James Heckman on discrimination, job training and early childhood education", "The Region", 2005, Vol. 6, 18-29.

Damasio A., The Feeling of What Happens: Body and Emotion in the Making of Con- $\mathbf{N r}$ 13(19) sciousness, Harcourt Brace, New York 2000.

de Waal F., Matpy i filozofowie. Skąd pochodzi moralność?, Copernicus Center Press, 2013.

Donohue J.J., The Search for Truth: In Appreciation of James J. Heckman, Stanford Law School, John M. Olin Program in Law and Economics, Working Paper 2001, No. 220.

Donohue J.J., The Search for Truth: In Appreciation of James J. Heckman, „Law\&Social Inquiry" 2002, Vol. 27, s. 23-34.

Flynn J.R., Massive IQ gains in 14 nations: what IQ tests really measure, „Psychological Bulletin" 1987, Vol. 101, s. 171-191.

Goldacre B., Złe leki. Jak firmy farmaceutyczne wprowadzaja w bład lekarzy i krzywdza pacjentów, Sonia Draga, Katowice 2013.

Haavelmo T., The statistical implications of a system of simultaneous equations, „Econometrica" 1943, Vol. 11, s. 1-12.

Heckman J., Payner B., Determining the Impact of Federal Antidiscrimination Policy on the Economic Status of Blacks, „The American Economic Review” 1989, Vol. 79, s. $138-177$.

Heckman J.J., Accounting for heterogeneity, diversity and general equilibrium in evaluating social programmes, „The Economic Journal” 2001, Vol. 111, s. 654-699.

Heckman J.J., Autobiographical chapter, [w:] W. Breit, B.T. Hirsch (red.), Lives of the Laureates: Twenty Three Nobel Laureates, Cambridge, Mass.: MIT Press, 2009, s. 299-334.

Heckman J.J., Sample Selection Bias as a Specification Error, „Econometrica” 1979, Vol. 47, s. 53-161.

Heckman J.J., The American family in Black \& White: A post-racial strategy for improving skills to promote equality, „Daedalus” 2011, Vol. 140, s. 70-89.

Heckman J.J., The Economics of Inequality: The Value of Early Childhood Education, „American Educator” 2011, Vol. 35, s. 31.

Heckman J.J., The scientific model of causality, „Sociological methodology” 2005, Vol. 35, s. 1-97.

Heckman J.J., Carneiro P., The Evidence on Credit Constraints in Post-secondary Schooling, „Economic Journal” 2002, Vol. 112, s. 705-734.

Heckman J.J., Interview by Donna Ginther, „Macroeconomic Dynamics” 2010a, Vol. 14, s. $548-584$.

Heckman J.J., Interviewed by D. Matthews, „The Washington Post” 14 February 2013.

Heckman J.J., LaLonde R.J., Smith J.A., The economics and econometrics of active labor market programs, „Handbook of labor economics” 1999, Vol. 3, s. 1865-2097.

Heckman J.J., Lyons T.M., Todd P.E., Understanding black-white wage differentials, 1960-1990, „American Economic Review” 2000, s. 344-349.

Heckman J.J., Prize Lecture: Microdata, Heterogeneity and the Evaluation of Public Policy, "Journal of Political Economy", 2000, Vol. 109, 673-748.

Heckman J.J., Rubinstein Y., The importance of noncognitive skills: Lessons from the GED testing program, „American Economic Review” 2001, s. 145-149.

Heckman, James J., Interview by John Cassidy, The New Yorker, 2010b, 14 January.

Herrnstein R.J., Murray Ch., "The Bell Curve”, Simon \& Schuster, USA, 1994.

Holliday R., Epigenetics: a historical overview, „Epigenetics” 2006 Vol. 1, s. 76-80.

Hume D., An Enquiry Concerning Human Understanding, London, 1777.

Jucewicz A., Sroczyński G., Żyj wystarczająco dobrze, Agora, 2013.

Kahneman D., Pułapki myślenia. O myśleniu szybkim i wolnym, Media Rodzina, 2012. 
Klein D.B., Daza R. “James J. Heckman”, “Economical Journal Watch”, 2013, Vol. 10, 358-366.

Nr 13(19) Klimczak B., Mikroekonomia, Wydawnictwo UE we Wrocławiu, Wrocław, 2011.

Lee L.-F., Some Approaches to the Correction of Selectivity Bias, „Review of Economic Studies" 1982, Vol. 49, s. 355-372.

Liesman S., Two U.S. Economists Win Nobel Prize, „The Wall Street Journal” 12 October 2000.

Little, R.J.A, Rubin D.B., Statistical Analysis with Missing Data, John Wiley \& Sons, New York 1987.

Marshall A., Principles of Economics, Macmillan and Company, New York 1890.

Mill, J. S., Principles of Political Economy with some of their Applications to Social Philosophy, J.W. Parker, London 1848.

Mischel W., Ebbesen E.B., Raskoff Zeiss A., Cognitive and attentional mechanisms in delay of gratification, ,Journal of Personality and Social Psychology” 1972, Vol. 21, s. 204-218.

Mischel W., Ayduk O., Willpower in a cognitive-affective processing system: The dynamics of delay of gratification, [w:] Baumeister R.F., Vohs K.D. (red.), Handbook of self-regulation: Research, Theory, and Applications, Guilford, New York 2004, s. $99-129$.

Moalem S., Inheritance: How Our Genes Change Our Lives - and Our Lives Change Our Genes, Grand Central Publishing, 2014.

Pelham B.W., Mirenberg M.C., Jones J.T., Why Susie sells seashells by the seashore: implicit egotism and major life decisions, „Journal of personality and social psychology" 2002, Vol. 82, s. 469.

Puhani P., The Heckman correction for sample selection and its critique, „Journal of Economic Surveys" 2000, Vol. 14, s. 53-68.

Schwarz B., Paradoks wyboru, Wydawnictw Naukowe PWN, Warszawa 2013.

Schweinhart L.J., Weikart D.P., High/Scope Perry Preschool Program effects at age twenty-seven, „Social programs that work” 1998, s. 148-162.

Simon H.A., Models of Man: Social and Rational, John Wiley and Sons, New York 1957.

Terman L.M. (red.), The gifted group at mid-life, Stanford University Press, Stanford, CA 1959.

Thaler R.H., Sunstein C.R., Impuls, Zysk i S-ka, Poznan 2008.

Tough P., Jak dzieci osiagaja sukces. Nauka sity woli i ciekawości świata, Wydawnictwo Nasza Księgarnia, Warszawa 2014.

\section{SAMPLES, RACIAL DISCRIMINATION AND EDUCATION: ECONOMETRICS AND SOCIAL ISSUES IN THE WORK OF JAMES J. HECKMAN (NOBEL MEMORIAL PRIZE IN ECONOMICS, 2000)}

Summary: James J. Heckman, the economist belonging to the so-called Chicago School, was awarded the Nobel Memorial Prize in Economics in 2000. His main contribution to microeconomics was developing methods for handling selective samples in a statistically satisfactory way. In social sciences Heckman is one of the main researchers of racial discrimination and education, with the special regard to the noncognitive aspects of the early education.

Keywords: econometrical model; selective sample; noncognitive aspects of education; J.J. Heckman. 